Eur. J. Clin. Chem. Clin. Biochem.

Vol. 31, 1993, pp. 225-231

(C) 1993 Walter de Gruyter \& Co.

Berlin - New York

\title{
Empirical Evaluation of Conditions \\ Influencing the Polymerase Chain Reaction: Enterotoxigenic Escherichia coli as a Test Case
}

\author{
By R. du Toit, T. C. Victor and P. D. van Helden \\ MRC Centre for Molecular and Cellular Biology, Department of Medical Physiology and Biochemistry, \\ University of Stellenbosch Medical School, Tygerberg, Republic of South Africa
}

(Received August 3/December 2, 1992

Summary: False polymerase chain reaction (PCR) results may be obtained under unfavourable reaction conditions. Therefore optimal conditions for the different factors influencing a specific PCR method should be determined before introduction to a clinical diagnostic laboratory. This study has concentrated on the detection of heat-labile enterotoxin-producing $E$. coli by PCR, with empirical evaluation of various factors. Template was prepared by heat-lysis of $E$. coli, and this was shown to be adequate for PCR detection. The results showed that deviation from the optimal conditions of any of the following conditions may lead to false results: lysis of bacterial cells, denaturation temperature during cycling, annealing temperature, primer concentration, enzyme concentration, magnesium concentration and ion concentration. Three different detection methods for PCR product were also evaluated. As little as one bacterium can be detected after 35 cycles of PCR amplification with ${ }^{32} \mathrm{P}$-labelled oligonucleotide probe. An alkaline phosphatase-labelled probe was 10-fold less sensitive, whereas 100 bacteria in $10 \mu \mathrm{l}$ of the original sample suspension were necessary to give a positive signal after gel electrophoresis. The information in this study may be useful to those who wish to introduce PCR tests to diagnostic laboratories.

\section{Introduction}

The polymerase chain reaction (PCR) is an in vitro method for the amplification of specific nucleic acid sequences by means of repeated cycles of DNA synthesis (1). This technique has been exploited in the analysis of genetic disorders (2), malignant diseases $(2,3)$ and in many infectious diseases $(4,5)$. For many diseases a number of slightly different diagnostic PCR methods have been described within a relatively short time. Such articles and methods are usually researchrelated and often describe development and testing of new primers and analysis of a few samples only (6, 7). These methods are not necessarily ready for use in routine laboratories, since problems can be encountered with contamination (8), the presence of inhibitors of the polymerase enzyme (9), or from unfavourable reaction conditions which influence sensitivity, leading to false negative or positive results. In order to avoid false results due to unfavourable reaction conditions, the factors that may influence such results have to be critically evaluated before being introduced to a clinical laboratory for routine analysis. Some attention has been devoted to the evaluation of factors influencing the PCR reaction (1, 10 ), but it is unlikely that there will be one set of optimal amplification conditions for all applications. Furthermore, it is evident that relatively pure nucleic acid polymers from eukaryotic cellular genes (11), viruses (12) and microbes (13), can be used for PCRanalysis, but little attention has been given to the evaluation of conditions influencing the PCR reaction when using crude templates. 
This study has concentrated on the conditions influencing the PCR-method for detecting heat-labile enterotoxin-producing $E$. coli. The information should be useful to other users of routine PCR assays and aid the introduction of PCR tests to diagnostic laboratories.

\section{Materials and Methods}

\section{Sample preparation}

Heat-labile enterotoxin-producing E. coli (ATCC 43886) was used as the subject of this study. E. coli was plated on McConkey plates and a scrape of the growth was taken and thoroughly mixed in $400 \mu \mathrm{l}$ sterile saline. Ten microlitres of this mixture were used for PCR amplification as described elsewhere (14). Sterile saline was used as a negative control.

DNA amplification by polymerase chain reaction

Oligonucleotide primers LT 51: CCGGTATTACAGAAATCTGA and LT31: GTGCATGATGAATCCAGGGT were designed to amplify a 110 base pair fragment of a conserved region of the toxA (A subunit) gene (14). The basic polymerase chain reaction is described below: the template $(10 \mu \mathrm{l} E$. coli suspension) was combined in a total volume of $99 \mu \mathrm{l}$ of a standard premixture of polymerase chain reaction buffer (10 $\mathrm{mmol} / \mathrm{l}$ Tris $-\mathrm{HCl}\left[\mathrm{pH} 9.0\right.$ at $\left.25^{\circ} \mathrm{C}\right], 1.5 \mathrm{mmol} / 1 \mathrm{MgCl}_{2}, 50$ $\mathrm{mmol} / 1 \mathrm{KCl}, 0.01 \mathrm{~g} / \mathrm{l}$ gelatin, $0.001 \mathrm{~g} / 1$ Triton X-100); a 200 $\mu \mathrm{mol} / \mathrm{l}$ final concentration (each) of dATP, dGTP, dCTP and dTTP; and each primer at $0.4 \mu \mathrm{mol} / \mathrm{l}$. The reaction mixture was heated at $95^{\circ} \mathrm{C}$ for 10 minutes to lyse the bacteria and denature the DNA. This was followed by centrifugation in an Eppendorf desktop centrifuge (15 s) and addition of $0.5 \mathrm{U}$ of Taq DNA polymerase (Promega). The mixture was overlaid with $40 \mu$ l of mineral oil. A heating cycle of $93^{\circ} \mathrm{C}$ for 1 minute, $58^{\circ} \mathrm{C}$ for 1 minute and $72^{\circ} \mathrm{C}$ for 2 minutes was repeated 35 times, followed by a final extension time of 10 minutes at $72^{\circ} \mathrm{C}$, in a thermal cycler. Variations from this standard protocol are described in the results section.

\section{Detection of PCR products}

Amplified DNA ( $20 \mu \mathrm{l}$ of $100 \mu \mathrm{l}$ reaction mix) was electrophoresed on a $1.7 \%$ agarose or $12 \%$ polyacrylamide gel, stained with ethidium bromide at a final concentration of $1 \mathrm{mg} / \mathrm{l}$, and visualised on a transilluminator. Hybridization and detection with a ${ }^{32} \mathrm{P}$-labelled probe (PLT1) or an alkaline phosphataselabelled probe (PLT2) were performed as described previously (14).

\section{Results}

Samples were directly amplified from saline suspensions by using heat-labile enterotoxin-specific primers. After thermal cycling, gel electrophoresis was done to detect a 110 base pair amplified product (14).

\section{Lysis time}

Lysis of bacteria by heat treatment at $95^{\circ} \mathrm{C}$ prior to amplification was investigated. Lysis time varied from 2 to 16 minutes. The product yield steadily increased as lysis time increased, but no further increase after 10 minutes at $95^{\circ} \mathrm{C}$ was evident (fig. 1).

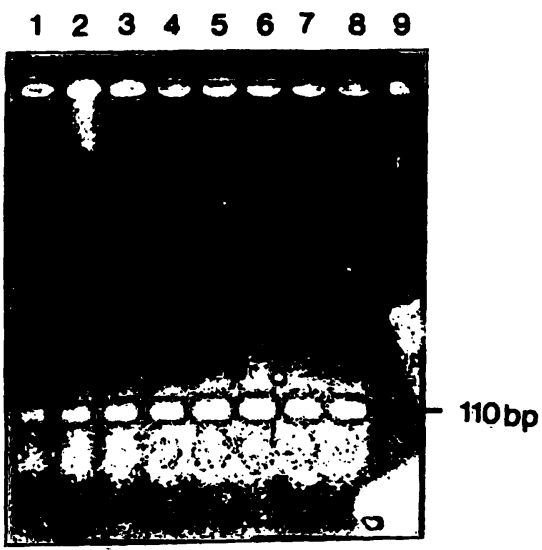

Fig. 1. Effect of lysis time on PCR DNA amplification. Samples were heat-treated at $95^{\circ} \mathrm{C}$ in order to lyse bacteria: 2 minutes (lane 1),

4 minutes (lane 2),

6 minutes (lane 3 ),

8 minutes (lane 4),

10 minutes (lane 5),

12 minutes (lane 6),

14 minutes (lane 7) and

16 minutes (lane 8).

After lysis, amplification was performed with heat-labile enterotoxin-specific primers. Twenty microlitres of amplified product were electrophoresed on a $1.7 \%$ agarose gel and visualized with ethidium bromide on a transilluminator. Fragments of 110 base pairs can be observed with an increasing sensitivity up to 10 minutes lysis time.

Lane 9 is a negative control, containing sterile saline as template.

\section{Denaturation temperature}

The standard protocol as described in materials and methods was used, but denaturation temperatures were $85^{\circ} \mathrm{C}, 90^{\circ} \mathrm{C}, 93^{\circ} \mathrm{C}$ and $97^{\circ} \mathrm{C}$ for 1 minute, respectively, in separate experiments. The product yield after denaturation at $85^{\circ} \mathrm{C}$ proved to be as efficient as at $93^{\circ} \mathrm{C}$; higher temperatures significantly reduced the product yield (fig. 2). Further experimentation showed that $93{ }^{\circ} \mathrm{C}$ was the initial maximum and that a temperature rise of even $0.5^{\circ} \mathrm{C}$ above $93^{\circ} \mathrm{C}$ resulted in inefficient amplification (result not shown).

\section{Annealing temperature}

Primer annealing temperatures may be calculated (15), but optimum temperatures should be determined empirically since they may be higher than predicted (16). Annealing time is usually in the order of one minute. Annealing was done at $45^{\circ} \mathrm{C}, 50^{\circ} \mathrm{C}, 58^{\circ} \mathrm{C}$, $62^{\circ} \mathrm{C}$ and $66^{\circ} \mathrm{C}$ for different cycles respectively for 1 minute. Optimum annealing was obtained at $58^{\circ} \mathrm{C}$ and the product yield decreased rapidly at $62{ }^{\circ} \mathrm{C}$ or higher temperatures (fig. 3). The optimum annealing temperature of $58^{\circ} \mathrm{C}$ corresponds well with the calculated melting temperatures of $56^{\circ} \mathrm{C}$ and $60^{\circ} \mathrm{C}$ for the two respective primers (14). 


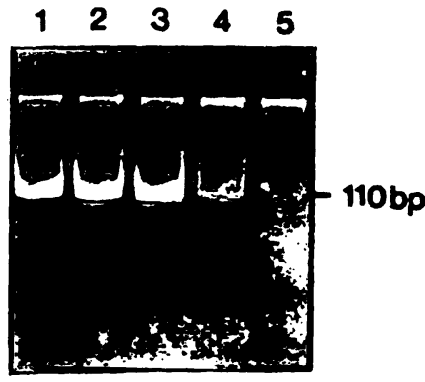

Fig. 2. Effect of denaturation temperature on PCR DNA amplification. Samples were lysed for 10 minutes at $95^{\circ} \mathrm{C}$ prior to PCR amplification. Denaturation temperatures during the reaction were

$85^{\circ} \mathrm{C}$ (lane 1 ),

$90^{\circ} \mathrm{C}$ (lane 2 ),

$93^{\circ} \mathrm{C}$ (lane 3),

$95^{\circ} \mathrm{C}$ (lane 4$)$ and

$97^{\circ} \mathrm{C}$ (lane 5).

Electrophoretic analysis was as described in figure 1.

123456

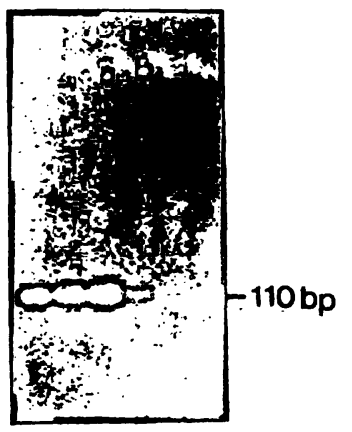

Fig. 3. Effect of annealing temperature on PCR DNA amplification. Samples were lysed for 10 minutes at $95^{\circ} \mathrm{C}$ prior to PCR amplification. The annealing temperature during the PCR amplification was

$45^{\circ} \mathrm{C}$ (lane 1 ),

$50^{\circ} \mathrm{C}$ (lane 2),

$58^{\circ} \mathrm{C}$ (lane 3 ),

$62^{\circ} \mathrm{C}$ (lane 4$)$ and

$66^{\circ} \mathrm{C}$ (lane 5).

Annealing temperature for the control saline (lane 6) was $58^{\circ} \mathrm{C}$.

Electrophoretic analysis was as described in figure 1.

\section{Primer concentration}

Primer concentration is equal in most PCR reports and is usually in the range of $0.1-1 \mu \mathrm{mol} / \mathrm{l}(17)$. High primer concentration may be the reason for mispriming or non-specific products (18). In this study, primer concentrations of $0.4-1 \mu \mathrm{mol} / \mathrm{l}$ gave optimal yields, but the product yield was significantly lower at 0.2 $\mu \mathrm{mol} / \mathrm{l}$ and $0.1 \mu \mathrm{mol} / 1$ (fig. 4).

\section{Enzyme concentration}

The source (10) and the amount of enzyme may have an influence on the efficiency of reaction and therefore on the success and final cost per assay. Therefore,

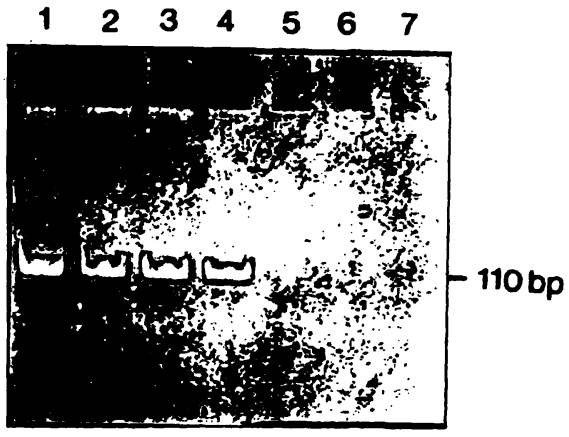

Fig. 4. Effect of primer concentration on PCR DNA amplification. The concentration of both primers was $1.0 \mu \mathrm{mol} / 1$ (lane 1 ),

$0.8 \mu \mathrm{mol} / 1$ (lane 2),

$0.6 \mu \mathrm{mol} / \mathrm{l}$ (lane 3 ),

$0.4 \mu \mathrm{mol} / 1$ (lane 4$)$,

$0.2 \mu \mathrm{mol} / \mathrm{l}$ (lane 5) and

$0.1 \mu \mathrm{mol} / 1$ (lane 6).

The concentration of both primers was $0.4 \mu \mathrm{mol} / 1$ for the control saline (lane 7).

Electrophoretic analysis was as described in figure 1.

enzyme concentrations ranging between $0.5 \mathrm{U}$ to $2 \mathrm{U}$ were tested. It was found that although $1.5 \mathrm{U}$ of enzyme gave optimum results, $0.5 \mathrm{U}$ of enzyme also gave sufficient product for positive identification. Thus, lower enzyme concentrations may still be useful for diseases where a high copy number of template is to be expected, as is the case for heat-labile enterotoxin-producing $E$. coli. The yield significantly decreased with higher concentrations $(2 \mathrm{U})$ of enzyme (fig. 5).

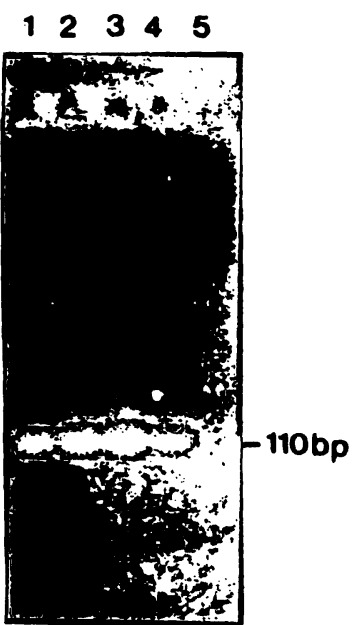

Fig. 5. Effect of enzyme concentration on PCR DNA amplification. The Taq polymerase concentration per reaction was

$0.5 \mathrm{U}$ (lane 1),

$1 \mathrm{U}$ (lane 2),

$1.5 \cup($ lane 3) and

2 U (lane 4).

The concentration of enzyme was $0.5 \mathrm{U}$ for the negative control (lane 5).

Electrophoretic analysis was as described in figure 1. 


\section{Magnesium concentration}

Magnesium ion concentration in most PCR protocols is between 0.5 and $10 \mathrm{mmol} / \mathrm{l}$ but the concentration of magnesium may often need individual optimization $(10,16)$. Concentrations between $0.2 \mathrm{mmol} / \mathrm{l}$ and 3.0 $\mathrm{mmol} / \mathrm{l}$ (final concentration) were tested in this study. No product was obtained at magnesium concentrations below $0.8 \mathrm{mmol} / \mathrm{l}$ and non-specific bands appeared at $3.0 \mathrm{mmol} / \mathrm{l}$ (fig. 6). The optimal concentration was determined to be $1.5 \mathrm{mmol} / \mathrm{l}$, and this was used routinely for all other amplifications.

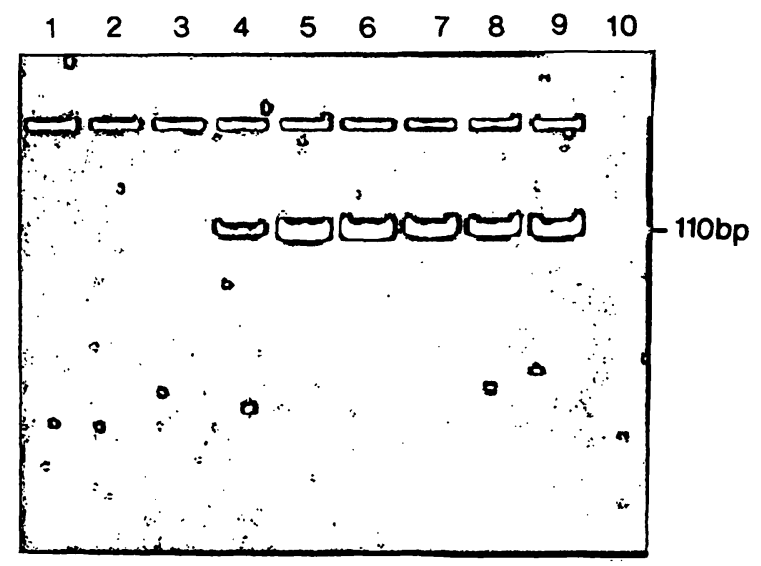

Fig. 6. Magnesium dependence of PCR DNA amplification. Samples were prepared as described and the magnesium ion concentration was

$0.2 \mathrm{mmol} / \mathrm{l}$ (lane 1$)$

$0.4 \mathrm{mmol} / \mathrm{l}$ (lane 2),

$0.8 \mathrm{mmol} / \mathrm{l}$ (lane 3),

$1.2 \mathrm{mmol} / \mathrm{l}$ (lane 4),

$1.5 \mathrm{mmol} / \mathrm{l}$ (lane 5),

$1.8 \mathrm{mmol} / \mathrm{l}$ (lane 6),

$2.0 \mathrm{mmol} / \mathrm{l}$ (lane 7 ),

$2.5 \mathrm{mmol} / \mathrm{l}$ (lane 8 ) and

$3.0 \mathrm{mmol} / \mathrm{l}$ (lane 9) in the PCR reaction buffer.

Lane 10 was sterile saline control $\left(1.5 \mathrm{mmol} / 1 \mathrm{Mg}^{2+}\right)$.

Electrophoretic analysis was as described in figure 1.

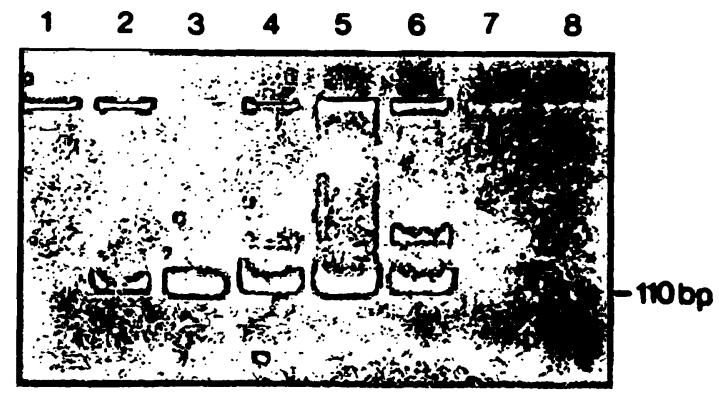

Fig. 7. Effect of number of cycles on PCR DNA amplification. The heat-labile enterotoxin gene was amplified in different test tubes for

15 cycles (lane 1 ),

25 cycles (lane 2 ),

35 cycles (lane 3 ),

45 cycles (lane 4$)$,

55 cycles (lane 5 ) and

65 cycles (lane 6 ).

Lanes 7 and 8 contain sterile saline and were amplified for 35 and 65 cycles respectively.

Electrophoretic analysis was as described in figure 1.
Number of cycles

The optimal number of cycles will depend upon the starting concentration of target DNA when other conditions are optimized. Usually $25-40$ cycles are performed, but too many cycles can increase the quantity and complexity of non-specific background products (16). Samples were analysed after amplification for $15,25,35,45,55$ and 65 cycles. An increase in product yield was obtained until 35 cycles, and the yield then approached a plateau, with the appearance of non-specific background products (fig. 7).

\section{Detection methods}

Different detection methods can be used for postPCR analysis and the application wil depend on the need. In this study three different methods were evaluated.

Serial dilutions of a 6 hour liquid culture of heatlabile enterotoxin-producing $E$. coli were made and $10 \mu$ of each dilution was subjected to PCR amplification. The number of bacteria in $10 \mu \mathrm{l}$ of the equivalent dilutions was also determined by assessing growth of a sample on L-agar plates after overnight incubation at $37^{\circ} \mathrm{C}$. Dot-blot detection was done as described previously (14). As little as 1 bacterium in $10 \mu \mathrm{l}$ could be detected after amplification using a ${ }^{32} \mathrm{P}$-labelled probe (PLT1) after 10 hours exposure of the filter (fig. 8a). No signal was obtained after 10 hours exposure of a negative control sample. The alkaline phosphatase probe (PLT2) was 10-fold less sensitive (fig. 8b), whereas 100 bacteria in $10 \mu$ l of the original saline suspension was necessary to give a positive signal after agarose gel electrophoresis (fig. 8c).

\section{Discussion}

The gene encoding the heat-labile enterotoxin is carried on a plasmid (26), and since this plasmid can readily transduce different strains of $E$. coli, a pathogenic strain is not easily identified $(10,19,21)$. A few DNA-based methods for detecting this gene and therefore the organism carrying it have been described $(14,22,23)$, amongst which are PCR-based methods $(14,22)$.

PCR-based identification methods have recently come to the fore as useful and potentially important adjuncts to the diagnostic laboratory, but the transfer from research laboratories to. routine laboratories seems to be slow. One of the reasons for this could be that results can be variable, since many conditions influence the success of the PCR test. Since the 
a

org $/ 10 \mu l$

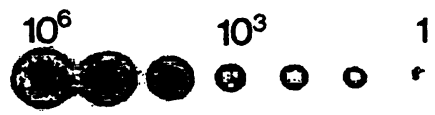

b

org / $10 \mu l$
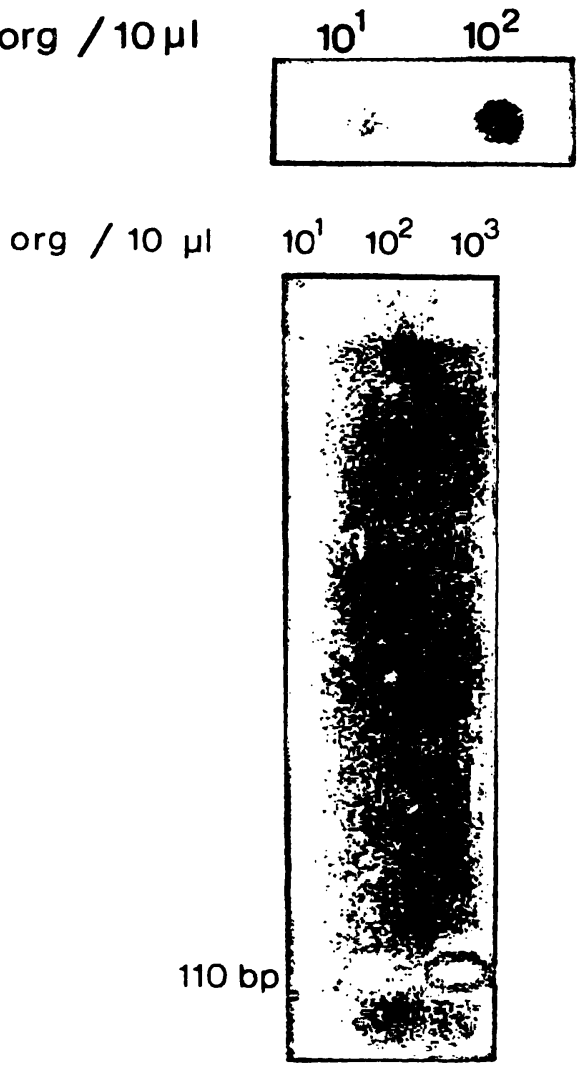

Fig. 8. Detection of PCR product. Serial dilutions of a $6 \mathrm{~h}$ culture of LT $+E$. coli were made and $10 \mu \mathrm{l}$ of each dilution was subjected to amplification. The number of bacteria (org) in $10 \mu \mathrm{l}$ of the equivalent dilutions was also determined by culture as described. Twenty-microlitre portions of the amplified product were used for dot-blot hybridization analysis and detected with ${ }^{32} \mathrm{P}$-labelled probe PLT1 after $10 \mathrm{~h}$ of exposure of the filter (a), or

detected with alkaline phosphatase-labelled probe PLT2 after 6 hours (b), or

detected with ethidium bromide after agarose gel electrophoresis (c) as described in the methods section.

method depends on the exponential amplification of a target nucleic acid sequence, a two-fold change in reaction efficiency may ultimately result in a 200 fold variation in product yield (10), and thereby be a determinant for success.

This study has concentrated on optimizing the various conditions influencing the efficiency of the PCR, in order that one efficient, reliable set of conditions may be established for routine use.

The results of this study show that a number of factors need to be evaluated, since any shift (excess or deficiency) from optimal conditions will result in the absence of the required product or appearance of spurious products, either of which represents a reaction failure and false results. Some of the influences which should be addressed are (i) sensitivity and specificity,

(ii) access to template (lysis of organism),

(iii) denaturation and annealing temperatures,

(iv) primer concentration,

(v) enzyme concentration,

(vi) ionic conditions, e. g. magnesium concentration,

(vii) number of cycles,

(viii) product detection methods.

These will be discussed briefly below.

\section{(i) Sensitivity and specificity}

The specificity of any PCR test needs to be carefully evaluated. In the case of the primers used in this study, this has been reported elsewhere (14). The sensitivity of the test has also been partly dealt with elsewhere (14), but can be as low as one organism in the test sample (see results) depending on the detection system used. As a research protocol, ${ }^{32} \mathrm{P}$-probe hybridization detection for sensitivity is to be recommended, but since most clinical infections involve a relatively large number of organisms, gel electrophoretic analysis in routine clinical situations is probably adequate. This system has the advantage of being less tedious and hazardous to personnel.

\section{(ii) Access to template}

Many procedures rely on prior DNA extraction for PCR-based methods for detection of DNA. These methods however, are too labour intensive and expensive to be used for screening large numbers of samples. Furthermore, the use of pure DNA as template does not exclude the possibility of contamination (27), nor the possibility that the so-called pure templates can still harbour inhibitors (6).

Many PCR methods $(11-13)$ report the use of crude sample preparations for amplification. However, inhibitors of the polymerase reaction (9) may be present in such samples and give rise to false negative results. In this study, we have used a relatively crude template (heat-lysed bacteria), which is adequate for PCR testing (14) and investigated the optimization of this procedure, since poor lysis due to insufficient lysis time may lead to false negative results. The time and conditions of bacterial lysis may vary for different bacteria; for example Mycobacterium, which has a relatively rigid cell wall. Sample preparation therefore remains one of the most important steps in any PCR protocol, and the complete process must be thoroughly evaluated to find the optimal conditions. 
(iii) Denaturation and annealing temperatures during PCR cycling

DNA denaturation is a critical step in PCR technology and in our experience deserves attention, whenever PCR fails (18). Template denaturation as a function of time and temperature must be evaluated, but without decreasing the (Taq) enzyme activity. Incomplete denaturation could occur if the temperature is not high enough, particularly in complex templates, such as the eukaryotic genome, which therefore biases the selection of elevated temperatures. However there is a sharp decline in efficiency of amplification above a certain temperature limit owing to denaturation of the polymerase. We suggest an initial 15 cycles of denaturation at high temperature (e.g. $93^{\circ} \mathrm{C}$ ) followed by the rest at lower temperature (e.g. $89^{\circ} \mathrm{C}$ ). The initial PCR (15 cycles) generates sufficient, easily denatured product for further amplification at lower (denaturation) temperatures. The temperature and time required for primer annealing depend upon the base composition, length, and concentration of the primers (18). Although this can be calculated (15), optimal conditions should be empirically determined, as in the present study.

\section{(iv) Primer concentration}

Low primer concentration can lead to PCR failure, while high concentrations of primers tend to inhibit the PCR, promote mispriming and the accumulation of non-specific products, as well as increasing the probability of generating primer-dimers (10). It was found that a primer concentration of $0.4 \mu \mathrm{mol} / 1$ is optimal for amplification of the heat-labile enterotoxin gene with the designed primers (14). No nonspecific bands were observed at this concentration.

\section{(v) Enzyme concentration}

It is known that the activity of Taq polymerases from different suppliers or from different batches may vary as much as two-fold, which may cause a 200 -fold variation in amplicon yield (10). Taq polymerase from the same batch was used in this study, and it was found that $1.5 \mathrm{U}$ per reaction gave the best results. Lower enzyme concentrations yielded sufficient amplified product for detection and may be sufficient for some applications (14), but optimal enzyme concentrations may be necessary for more sensitive detection systems, e.g. for $M$. tuberculosis. No explanation could be found for the decrease in yield with higher concentrations of enzyme.

(vi) Magnesium concentration

Enzyme activity is also influenced by the magnesium ion concentration, and enzyme batches which require high amounts of magnesium are generally less active than those with a lower magnesium ion requirement. Magnesium concentrations may also affect the strand dissociation temperatures of both template and PCR product, as well as the formation of primer-dimer artefacts (24). As magnesium ions bind stoichiometrically to deoxynucleotide triphosphates and to pyrophosphate, a by-product of the extension reaction, the exact magnesium concentration required to activate the enzyme maximally is dependent on the dNTP concentration (18). Therefore, the ratio of the dNTPs to magnesium must not be so high as to remove the divalent cation from the reaction. It has been found that Taq polymerase has two magnesium optima (10); the free magnesium ion concentration should therefore be optimized for specific PCR experiments (18, 25).

\section{(vii) Cycle number}

The optimal number of cycles will depend mainly on the initial concentration of template when other conditions are optimized. Increasing the number of cycles is not an effective strategy for overcoming low efficiency in individual cycles; rather, variables such as primer, enzyme or magnesium-ion concentrations should be more thoroughly examined, or a small aliquot of the initial reaction should be re-amplified (8).

\section{(viii) Product detection}

The detection method used will depend on the specific application. Gel electrophoresis is the preferred method for most applications. It is suggested that gel electrophoresis is sufficient for routine diagnosis of this pathogen, since the number of heat-labile enterotoxin-producing $E$. coli required to produce clinical symptoms, is also sufficient for detection (14). The extra detection systems may prove useful in testing the environment for this pathogen, however, since fewer organisms are then encountered.

The polymerase chain reaction is a powerful and increasingly popular technique in molecular biology (4). It is clear that the individual conditions influencing the reaction should be optimized, in order to render any given test as sensitive and reliable as possible. Errors such as false positive and false negative results are then be minimized, and the interpretation of results is more reliable. It should be noted that although this study focussed on the conditions influencing the PCR method, other problems such as contamination (8) or inhibitors (9), must also be considered and are no less important. 


\section{References}

1. Mullis, K. B. \& Faloona, F. A. (1987) Specific synthesis of DNA in vitro via a polymerase-catalyzed chain reaction. Methods Enzymol. 155, 335-350.

2. Boechm, C. D. (1989) Use of polymerase chain reaction for diagnosis of inherited disorders. Clin. Chem. 35, 18431848.

3. Mc Donnell, J. M., Mayr, A. J. \& Martin, W. J. (1989) DNA of human papillomavirus type 16 in dysplastic and malignant lesions of the conjunctiva and cornea. N. Engl. J. Med. 320, $1442-1446$.

4. Eisenstein, B. I. (1990) The polymerase chain reaction: A new method of using molecular genetics for medical diagnosis. N. Engl. J. Med. 322, 178-183.

5. Yen, T. S. B. (1988) Using the polymerase chain reactions in detecting infectious agents. West. J. Med. 149, 597.

6. Thierry, D., Brisson-Noël, A., Vincent-Lévy-Frébault, V., Nguyen, S., Guesdon, J-L. \& Gicquel, B. (1990) Characterization of a Mycobacterium tuberculosis insertion sequence, IS6110, and its application in diagnosis. J. Clin. Microbiol. 28, 2668-2673.

7. De Wit, D., Steyn, L., Schoemaker, S. \& Sogin, M. (1990) Direct detection of Mycobacterium tuberculosis in clinical specimens by DNA amplification. J. Clin. Microbiol. 28, $2437-2441$.

8. Kitchin, P. A., Szotyori, Z., Fromholc, C. \& Almond, N. (1990) Avoidance of false positives. Nature 344, 201.

9. Demmler, G. L., Buffone, G. J., Schimbor, C. M. \& May, R. A. (1988) Detection of cytomegalovirus in urine from newborns by using PCR DNA amplification. J. Infect. Dis. $158,1177-1184$.

10. Linz, U., Delling, U. \& Rübsamen-Waigmann, H. (1990) Systematic studies on parameters influencing the performance of teh polymerase chain reaction. J. Clin. Chem. Clin. Biochem. 28, 5-13.

11. Almoguera, C., Shibata, D., Forrester, K., Martin, J., Arnheim, N. \& Perucho, M. (1988) Most human carcinomas of the exocrine pancreas contain mutant c-K-ras genes. Cell $53,549-554$.

12. Claas, E. C. J., Melchers, W. J. G., Van der Linden, H. C., Lindeman, J. \& Quint, W. G. V. (1989) Human papillomavirus detection in paraffin-embedded cervical carcinomas and metastases of the carcinomas by the polymerase chain reaction. Am. J. Pathol. 135, 703-709.

13. Fries, J. W. U., Patel, R. J., Piessens, W. F. \& Wirth, D. F. (1991) Detection of untreated mycobacteria by using polymerase chain reaction and specific DNA probes. J. Clin. Microbiol. 29, 1744-1747.

14. Victor, T., Du Toit, R., Van Zyl, J., Bester, A. J. \& Van Helden, P. D. (1991) An improved method for the routine diagnosis of enterotoxigenic Escherichia coli by DNA amplification of a conserved region of the Toxin A subunit. J. Clin. Microbiol. 29, 158-161.
15. Diaz-Chico, J. C., Yang, K., Efromov, D. G., Soming, T. A. \& Huiman, T. H. J. (1988) The detection of beta-globulin gene mutations in beta-thalassemia using oligonucleotide probes and amplified DNA. Biochim. Biophys. Acta 949, $43-48$.

16. Williams, J. F. (1989) Optimization strategies for the polymerase chain reaction. Biotechniques $7,762-768$.

17. Li, H., Cui, X. \& Arnheim, N. (1990) Direct electrophoretic detection of the allelic state of single DNA molecules in human sperm by using the polymerase chain reaction. Proc. Natl. Acad. Sci. USA 87, 4580-4584.

18. Gelfand, D. H. \& White, T. J. (1990) Thermostable DNA Polymerases. In: PCR Protocols: $A$ Guide to Methods and Applications (Innis, M. A., Gelfand, D. H., Sninsky, J. J. \& White, T. J., eds.) pp. 129-141, Academic Press, Inc. California.

19. Konowalchuk, J. \& Speirs, J. I. (1979) Response of various cell lines to Escherichia coli toxic products. Can. J. Microbiol. 25, 335-339.

20. Sack, D. A. \& Sack, R. B. (1975) Test for entertoxigenic Escherichia coli using Y1 adrenal cells in miniculture. Infect. Immun. 11, 334-336.

21. Speirs, J. I., Stavric, S. \& Konowalchuk, J. (1977) Assay of Escherichia coli heat-labile enterotoxin with Vero cells. Infect. Immun. 16, 617-622.

22. Olive, D. M., Atta, A. I. \& Setti, S. K. (1988) Detection of toxigenic Escherichia coli using biotin-labelled DNA probes following enzymatic amplification of the heat-labile toxin gene. Mol. Cell Probes 2, 47-57.

23. Sommerfelt, H. S., Grewal, H. M. S. \& Bhan, M. K. (1990) Simplified and accurate nonradioactive polynucleotide gene probe assay for identification of enterotoxigenic Escherichia coli. J. Clin. Microbiol. 28, 49-54.

24. Watson, R. (1989) The formation of primer artifacts in polymerase chain reaction. Amplifications 2, 5-6.

25. Saiki, R. K., Gelfand, D., Oste, D. \& Higuchi, R. (1989) Basic methodology part one. In: PCR Technology, 1st ed. (Erlich, H. A., ed.) pp. 1-38, Stockton Press, New York.

26. Yamamoto, T., Tamura, T. \& Yokota, T. (1984) Primary structure of heat-labile enterotoxin produced by Escherichia coli pathogenic for humans. J. Biol. Chem. 259, 50375044.

27. Pierre, C., Lecossier, D., Boussougant, Y., Bocart, D., Joly, V., Yeni, P. \& Hance, A. J. (1991) Use of reamplification protocol improves sensitivity of detection of Mycobacterium tuberculosis in clinical samples by amplification of DNA. J. Clin. Microbiol. 29, 712-717.

\section{Rene du Toit}

MRC Centre for Molecular and Cellular Biology Department of Medical Physiology and Biochemistry

University of Stellenbosch Medical School

P. O. Box 19063

Tygerberg

7505

Republic of South Africa 
